\title{
Relationship Between Health Literacy and Social Support and the Quality of Life in Patients With Cancer: Questionnaire Study
}

Rei Kobayashi, MSc; Masato Ishizaki, PhD

Interfaculty Initiative in Information Studies, The University of Tokyo, Tokyo, Japan

Corresponding Author:

Rei Kobayashi, MSc

Interfaculty Initiative in Information Studies

The University of Tokyo

7-3-1, Hongo, Bunkyo-ku

Tokyo, 113-0033

Japan

Phone: 81358415925

Fax: 81358415925

Email: rei-kobayashi@hotmail.co.jp

\section{Abstract}

Background: Low health literacy is associated with factors such as not taking medication as prescribed as well as poor health status and increased hospitalization and mortality risk, and has been identified as a risk factor for decreased physical function in older individuals. Health literacy is becoming an increasingly important issue because of the increased number of people affected by cancer who must make complicated treatment decisions. Health literacy has been shown to be positively associated with quality of life (QOL), and social support has been identified as important for addressing health-related problems and reducing the relative risk of mortality in patients with cancer. However, few studies have examined the relationship between health literacy, social support, age, and QOL.

Objective: The aim of this study is to examine the effects of health literacy, social support, and age on the QOL of patients with cancer.

Methods: An anonymous, self-administered online questionnaire was conducted from March 28 to 30, 2017, in Japan on patients with lung, stomach, or colon cancer that were voluntarily registered with an internet survey company. The survey covered basic attributes, health literacy, social support, and QOL. The European Health Literacy Survey Questionnaire, a comprehensive measure of health literacy instrument, was used to measure health literacy; the Japanese version of the Social Support Scale was used to measure social support; and the Japanese version of the Functional Assessment of Cancer Therapy-General (7-item version) assessment tool was used to measure QOL.

Results: A total of 735 survey invitations were randomly sent to patients with lung, stomach, or colorectal cancer, and responses were obtained from 619 (82.2\% response rate). Significant effects on the QOL in patients with lung, stomach, or colon cancer were observed for health literacy, social support, and age, and for the interactions of health literacy and social support and of social support and age. Health literacy, social support, and the interaction between these variables also showed a significant effect on the QOL in patients 50 years or older, but not on those younger than 50 years.

Conclusions: The results of this study revealed that higher health literacy, social support, and age were associated with the QOL in patients with cancer. In addition, the relationship with QOL was stronger for social support than for health literacy. These findings suggest the importance of health literacy and social support and indicate that social support has a greater effect on QOL than does health literacy, while the QOL in patients with cancer aged younger than 50 years was lower than that of those 50 years or older. Therefore, elucidating the needs of these patients and strengthening social support based on those needs may improve their QOL.

(J Participat Med 2020;12(1):e17163) doi: $\underline{10.2196 / 17163}$

\section{KEYWORDS}

health literacy; social support; quality of life; neoplasms; health communication 


\section{Introduction}

\section{Health Literacy and Quality of Life in Patients With Cancer}

Health literacy is the ability to obtain, understand, evaluate, and use information about health and medical care [1]. Low health literacy is associated with poor health status, limited access to health care, increased use of expensive health care services, and high mortality rates [2-4]. In addition, it is associated with not taking medication as prescribed [5,6] as well as increased hospitalization and mortality risk in patients with a history of heart failure [7]. Among older individuals, low health literacy has been identified as a risk factor for decreased physical function [8]. Moreover, in terms of prevention, low health literacy has been found to be associated with low participation in colorectal cancer screening [9].

Increasing numbers of people worldwide are afflicted by and die from cancer [10-13]. Patients with cancer must make complicated decisions that have a major effect on their treatment and future; thus, health literacy is a particularly important issue [14]. Low health literacy can result in the misunderstanding of a disease, inadequate treatment due to the inability to communicate satisfactorily with health care personnel, and an inability to comply with treatment plans [15-17].

The World Health Organization defines quality of life (QOL) as an individual's perception of their position in life in the context of the culture and value systems where they live and in relation to their goals, expectations, standards, and concerns [18]. Considering the continuous care required for patients with cancer, including the use of medical care services, routine health management, and end-of-life medical care, health literacy has a major effect on QOL [19-22]. In a previous study [23], health literacy was found to be positively associated with QOL.

Efforts to increase health literacy appear in national policies in the form of programs such as the National Action Plan to Improve Health Literacy in the United States [24] and The Japan Vision: Health Care 2035 [25]. However, the results have been less than satisfactory [26]. Moreover, health literacy does not increase with health care experience [27]. The findings of these previous reports suggest that improving health literacy is not a straightforward task.

\section{Social Support and Quality of Life in Patients With Cancer}

The QOL in patients with cancer has been found to be affected by the attributes and psychological and physical health of the individual [28-30], and by symptoms and levels of high anxiety after cancer treatment [31]. These factors have been found to be important in facilitating adaptation to daily life following treatment [32]. In addition, social support has been identified as an important means of addressing health-related problems [33]. A study of patients with lung cancer suggested that social and emotional support are important for QOL [34]. Moreover, strong social support has been shown to reduce the relative risk of mortality in patients with cancer [35]. A study of aged survivors of cancer found that QOL was high in individuals with strong emotional support and low in those with weak emotional support [36]. Further, in a study of aged patients with cancer undergoing chemotherapy, QOL was higher in those with strong social support [37], and in patients with colon or rectal cancer, QOL increased with stronger social support [38]. However, to our knowledge, health literacy and QOL and social support and QOL have only been studied separately; few studies have examined the relationship between health literacy and social support.

\section{Health Literacy, Social Support, Age, and Quality of Life in Patients With Cancer}

Lee (2004) [33] posed a research question on health literacy, social support, and QOL regarding whether social support can mitigate low health literacy and improve QOL. In addition, a similar study found that low health literacy and a high degree of social isolation were independently associated with increased mortality risk [39]. A high degree of social isolation and weak social support may overlap, and mortality can be understood as an objective number. The present study takes Lee's (2004) [33] research question seriously, and in doing so, attempts to clarify the relationship between QOL and health literacy and social support in patients with cancer (research question 1).

Lee (2009) [40] examined health literacy, social support, and QOL in relation to Medicare in the United States, and found positive correlations between high health literacy, high social support, and better QOL. An examination of cancer mortality risk according to age reported that the risk of cancer mortality increases with age. According to the American Cancer Society, $80 \%$ or more of patients diagnosed with cancer in the United States are 55 years or older [41]. In the United Kingdom, the incidence of cancer rapidly increases beginning at around 55 years of age, according to Cancer Research UK [42]. In Japan, the risk of cancer for both men and women starts to increase when people are in their 50s [43]. Consequently, in addition to research question 1, this study examined the relationship between QOL and health literacy and social support in patients aged 50 years or older and patients younger than 50 years, and whether there were differences between these two groups (research question 2). This approach was based on facts that Smith et al (2018) [39] previously looked at in patients 50 years or older, and cancer risk begins to increase when people reach their 50s.

\section{Methods}

\section{Participants}

An anonymous, self-administered, online questionnaire survey was conducted from March 28 to 30, 2017, by an internet survey company in Japan. The survey participants were recruited from voluntarily registered patients with lung, stomach, or colon cancer. These types of cancer were selected because they ranked as the top three for cancer mortality in Japan [43]. In total, 735 potential respondents (diagnosed with lung, stomach, or colon cancer, and between the ages of 20-69 years) were randomly invited by email to participate in an anonymous, cross-sectional online survey, and 619 accepted the invitation and responded (collection rate $82.2 \%$ ). The survey data were anonymized and managed so that individuals involved in the study could not be 
identified. This study was approved by the institutional review board of the University of Tokyo Interfaculty Initiative in Information Studies.

\section{Measures}

The survey covered basic attributes, health literacy, social support, and QOL. The instrument used to measure health literacy was the European Health Literacy Survey Questionnaire (HLS-EU-Q47), a comprehensive measure of health literacy. The reliability and validity of the questionnaire has been confirmed for not only the original version, but also the Japanese translation (HLS-EU-Q47 Japanese Version) [44]. The HLS-EU-Q47 is not targeted at patients with cancer, and its items can be divided into three areas: health care, disease prevention, and health promotion. Because the participants in this study were patients with cancer, the survey was narrowed to 16 health care items related to the health care experiences of patients with cancer. The items asked whether the participants were able to find information on their disease and its treatment, whether they understood the information they obtained from physicians, and whether they understood the medications they received.

To measure social support, the Japanese version of the Social Support Scale $[45,46]$ was used. The reliability and validity of the Japanese version of the scale have been validated. The Japanese version of the Functional Assessment of Cancer Therapy-General (7-item version) (FACT-G7) version 4 assessment tool was used to measure QOL [47]. The Functional Assessment of Cancer Therapy-General (FACT-G) has been used in studies of QOL and health literacy in patients with cancer [23]. Although the FACT-G7 is an abbreviated version of the established FACT-G, its effectiveness has been confirmed to be interchangeable with that of the FACT-G [48]. The FACT-G7 was used in this study to minimize the burden on the survey participants.

\section{Analysis}

For health literacy, responses to the 16-item Japanese version of the HLS-EU-Q47 questionnaire were obtained as a score of 1 to 4 points on a 4-point Likert scale (from very easy to very difficult, reverse-scored items) or 0 (do not know). For social support, responses to the 12-item Japanese version of the Social Support Scale were obtained as a score of 1 to 5 points on a 5-point Likert scale (from disagree to agree). Responses to the 7-item Japanese version of the FACT-G7 (version 4) were obtained as a score of 1 to 5 points on a 5-point Likert scale (from very much to not at all). Reverse-scored items were adjusted so that 5 indicated a high QOL and 1 indicated a low QOL. The mean score for the seven items was used for QOL. All the variables of each construct were calculated as the sums of the item scores.

A multiple regression analysis performed with QOL as the dependent variable used age, sex, household income, educational level, time since diagnosis, type of cancer, and disease stage as dummy variables when the survey was conducted, and the standardized values (z scores) of the total score for the 16 health literacy items and the total score for the 12 social support items were used as independent variables. Statistical analysis was performed using SPSS version 24 (IBM Corp, Armonk, NY) and R 3.6.1 software (R Foundation for Statistical Computing, Vienna, Austria).

\section{Results}

\section{Participants}

The characteristics of the survey participants are shown in Table 1. The mean health literacy, social support, and QOL values were 2.25 (SD 0.71), 3.52 (SD 0.94), and 3.41 (SD 0.80), respectively. Dividing the participants into two groups based on age, the values were 2.29 (SD 0.67), 3.63 (SD 0.92), and 3.66 (SD 0.78), respectively, for those aged 50 years or older and 2.19 (SD 0.78), 3.35 (SD 0.95), and 3.05 (SD 0.69), respectively, for those younger than 50 years. 
Table 1. Characteristics of the survey participants.

\begin{tabular}{|c|c|c|c|}
\hline Characteristics & Total $(\mathrm{N}=619), \mathrm{n}(\%)$ & Age $\geq 50$ years $(\mathrm{n}=376), \mathrm{n}(\%)$ & Age $<50$ years $(\mathrm{n}=243), \mathrm{n}(\%)$ \\
\hline \multicolumn{4}{|l|}{ Sex } \\
\hline Male & $477(77.1)$ & $317(84.3)$ & $160(65.8)$ \\
\hline Female & $142(22.9)$ & $59(15.7)$ & $83(34.2)$ \\
\hline \multicolumn{4}{|l|}{ Household income (million JPY) } \\
\hline$<4$ & $157(25.4)$ & $107(28.5)$ & $50(20.6)$ \\
\hline$\geq 4$ and $<8$ & $209(33.8)$ & $123(32.7)$ & $86(35.4)$ \\
\hline$\geq 8$ & $178(28.8)$ & $110(29.3)$ & $68(28.0)$ \\
\hline Unknown or not available & $75(12.1)$ & $36(9.6)$ & $39(16.0)$ \\
\hline \multicolumn{4}{|l|}{ Educational attainment } \\
\hline Less than university degree & $253(40.9)$ & $159(42.3)$ & $94(38.7)$ \\
\hline University/graduate degree & $354(57.2)$ & $208(55.3)$ & $146(60.1)$ \\
\hline Other or unknown & $12(1.9)$ & $9(2.4)$ & $3(1.2)$ \\
\hline \multicolumn{4}{|l|}{ Time since diagnosis } \\
\hline$<6$ months & $99(16)$ & $51(13.6)$ & $48(19.8)$ \\
\hline$\geq 6$ months and $<1$ year & $82(13.2)$ & $42(11.2)$ & $40(16.5)$ \\
\hline$\geq 1$ year and $<2$ years & $182(29.4)$ & $113(30.1)$ & $69(28.4)$ \\
\hline$\geq 2$ years & $256(41.4)$ & $170(45.2)$ & $86(35.4)$ \\
\hline \multicolumn{4}{|l|}{ Site of primary tumor } \\
\hline Lung & $119(19.2)$ & $57(15.2)$ & $62(25.5)$ \\
\hline Stomach & $206(33.3)$ & $124(33.0)$ & $82(33.7)$ \\
\hline Colon & $294(47.5)$ & 195 (51.9) & $99(40.7)$ \\
\hline \multicolumn{4}{|l|}{ Cancer stage } \\
\hline I & $250(40.4)$ & $151(40.2)$ & 99 (40.7) \\
\hline II & $133(21.5)$ & $65(17.3)$ & $68(28.0)$ \\
\hline III & 103 (16.6) & $64(17.0)$ & $39(16.0)$ \\
\hline IV & $50(8.1)$ & $32(8.5)$ & $18(7.4)$ \\
\hline Unknown & $83(13.4)$ & $64(17.0)$ & $19(7.8)$ \\
\hline
\end{tabular}

\section{Quality of Life in Patients With Cancer}

A multiple regression analysis including dummy variables was performed with QOL as the dependent variable, and the model shown in Table 2 was obtained $\left(F_{22,596}=811.99 ; P<.001\right.$; adjusted $\mathrm{R}^{2}=0.281$ ). In this model, the standard partial regression coefficients were significant for age, health literacy, social support, interaction of health literacy and social support, and interaction of social support and age. 
Table 2. Multiple regression analysis of quality of life for all participants.

\begin{tabular}{|c|c|c|c|c|c|}
\hline Variables & $\mathrm{B}$ & SE & Beta & $P$ value & Variance inflation factor \\
\hline (Constants) & 3.453 & 0.110 & $\mathrm{~N} / \mathrm{A}^{\mathrm{a}}$ & $<.001$ & N/A \\
\hline Female (reference male) & 0.105 & 0.070 & .055 & .13 & 1.140 \\
\hline Age $\geq 50$ years (reference $<50$ years) & 0.526 & 0.061 & .320 & $<.001$ & 1.184 \\
\hline $\begin{array}{l}\text { Household income } \geq 4 \text { and }<8 \text { million JPY (reference }<4 \text { mil- } \\
\text { lion JPY) }\end{array}$ & -0.040 & 0.074 & -.024 & .59 & 1.637 \\
\hline Household income $\geq 8$ million JPY (reference $<4$ million JPY) & -0.026 & 0.079 & -.015 & .79 & 1.704 \\
\hline $\begin{array}{l}\text { Household income unknown or not available (reference }<4 \\
\text { million JPY) }\end{array}$ & -0.187 & 0.098 & -.076 & .06 & 1.373 \\
\hline $\begin{array}{l}\text { University/graduate degree (reference less than university } \\
\text { degree) }\end{array}$ & 0.035 & 0.060 & .022 & .55 & 1.158 \\
\hline Other/unknown (reference less than university degree) & 0.112 & 0.208 & .019 & .59 & 1.101 \\
\hline $\begin{array}{l}\text { Time since diagnosis } \geq 6 \text { months and }<1 \text { year (reference }<6 \\
\text { months) }\end{array}$ & -0.111 & 0.104 & -.047 & .29 & 1.657 \\
\hline Time since diagnosis $\geq 1$ and $<2$ years (reference $<6$ months) & 0.086 & 0.087 & .049 & .32 & 2.100 \\
\hline Time since diagnosis $\geq 2$ years (reference $<6$ months) & -0.006 & 0.083 & -.003 & .95 & 2.244 \\
\hline Stomach cancer (reference lung cancer) & 0.016 & 0.081 & .010 & .84 & 1.940 \\
\hline Colon cancer (reference lung cancer) & 0.199 & 0.078 & .124 & .01 & 2.019 \\
\hline Stage II (reference Stage I) & -0.301 & 0.075 & -.154 & $<.001$ & 1.266 \\
\hline Stage III (reference Stage I) & -0.237 & 0.082 & -.110 & .004 & 1.242 \\
\hline Stage IV (reference Stage I) & -0.622 & 0.109 & -.211 & $<.001$ & 1.167 \\
\hline Stage unknown (reference Stage I) & -0.020 & 0.090 & -.008 & .82 & 1.254 \\
\hline Health literacy & 0.106 & 0.029 & .132 & $<.001$ & 1.106 \\
\hline Social support & 0.169 & 0.029 & .210 & $<.001$ & 1.096 \\
\hline Health literacy $*$ Social support & -0.050 & 0.025 & -.073 & .047 & 1.139 \\
\hline Health literacy * Age & 0.069 & 0.057 & .043 & .23 & 1.084 \\
\hline Social support * Age & 0.196 & 0.057 & .119 & .001 & 1.039 \\
\hline Health literacy * Social support * Age & -0.082 & 0.048 & -.061 & .09 & 1.126 \\
\hline
\end{tabular}

${ }^{\mathrm{a} N} / \mathrm{A}$ : not applicable.

\section{Quality of Life According to Age}

A multiple regression analysis including dummy variables was performed for individuals aged 50 years or older with QOL as the dependent variable, and the model shown in Table 3 was obtained $\left(\mathrm{F}_{18,357}=7.33 ; P<.001\right.$; adjusted $\left.\mathrm{R}^{2}=0.233\right)$.

In this model, the standard partial regression coefficients were significant for health literacy, social support, and the interaction between health literacy and social support.

The results of a simple slope analysis for the interaction of health literacy and social support are shown in Table 4 and
Figure 1. For health literacy and social support, a value below the mean was considered low, and a value equal to or above the mean was considered high.

A significant association was seen between QOL and social support, regardless of the level of health literacy $(P<.001)$. However, the coefficient for social support was larger when health literacy was low compared with when it was high.

Next, a multiple regression analysis including dummy variables was performed with QOL as the dependent variable for participants younger than 50 years; the results were not significant $\left(\mathrm{F}_{18,224}=1.63, P=.06\right)$. 
Table 3. Multiple regression analysis of quality of life in patients aged 50 years or older.

\begin{tabular}{|c|c|c|c|c|c|}
\hline Variables & $\mathrm{B}$ & SE & Beta & $P$ value & Variance inflation factor \\
\hline (Constant) & 3.647 & 0.150 & $\mathrm{~N} / \mathrm{A}^{\mathrm{a}}$ & $<.001$ & N/A \\
\hline Female (reference male) & 0.094 & 0.103 & .044 & .36 & 1.115 \\
\hline $\begin{array}{l}\text { Household income } \geq 4 \text { and }<8 \text { million JPY (reference }<4 \text { mil- } \\
\text { lion JPY) }\end{array}$ & -0.110 & 0.094 & -.066 & .24 & 1.541 \\
\hline Household income $\geq 8$ million JPY (reference $<4$ million JPY) & -0.059 & 0.099 & -.034 & .56 & 1.617 \\
\hline $\begin{array}{l}\text { Household income unknown or not available (reference }<4 \\
\text { million JPY) }\end{array}$ & -0.388 & 0.135 & -.146 & .004 & 1.255 \\
\hline $\begin{array}{l}\text { University/graduate degree (reference less than university } \\
\text { degree) }\end{array}$ & 0.059 & 0.078 & .037 & .45 & 1.204 \\
\hline $\begin{array}{l}\text { Other or unknown education (reference less than university } \\
\text { degree) }\end{array}$ & 0.068 & 0.245 & .013 & .78 & 1.120 \\
\hline $\begin{array}{l}\text { Time since diagnosis } \geq 6 \text { months and }<1 \text { year (reference }<6 \\
\text { months) }\end{array}$ & -0.071 & 0.148 & -.028 & .63 & 1.737 \\
\hline Time since diagnosis $\geq 1$ and $<2$ years (reference $<6$ months) & 0.093 & 0.118 & .055 & .43 & 2.354 \\
\hline Time since diagnosis $\geq 2$ years (reference $<6$ months) & 0.067 & 0.113 & .043 & .55 & 2.522 \\
\hline Stomach cancer (reference lung cancer) & 0.089 & 0.113 & .053 & .43 & 2.256 \\
\hline Colon cancer (reference lung cancer) & 0.276 & 0.108 & .176 & .01 & 2.324 \\
\hline Stage II (reference Stage I) & -0.431 & 0.105 & -.208 & $<.001$ & 1.254 \\
\hline Stage III (reference Stage I) & -0.251 & 0.107 & -.121 & .02 & 1.279 \\
\hline Stage IV (reference Stage I) & -0.697 & 0.138 & -.249 & $<.001$ & 1.180 \\
\hline Stage unknown (reference Stage I) & -0.121 & 0.107 & -.058 & .26 & 1.294 \\
\hline Health literacy & 0.125 & 0.039 & .150 & .002 & 1.087 \\
\hline Social support & 0.246 & 0.038 & .306 & $<.001$ & 1.093 \\
\hline Health literacy $*$ Social support & -0.083 & 0.036 & -.109 & .02 & 1.085 \\
\hline
\end{tabular}

${ }^{\mathrm{a}} \mathrm{N} / \mathrm{A}$ : not applicable.

Table 4. Simple slope analysis for interaction of health literacy and social support.

\begin{tabular}{lllll}
\hline Variables & Simple slope & SE & $t_{357}(2$-tailed $)$ & $P$ value \\
\hline Low health literacy (-1 SD) & 0.33 & 0.05 & 6.56 & $<.001$ \\
High health literacy (+1 SD) & 0.17 & 0.05 & 3.34 & $<.001$
\end{tabular}


Figure 1. Relationship between health literacy and social support and the quality of life in patients 50 years or older.

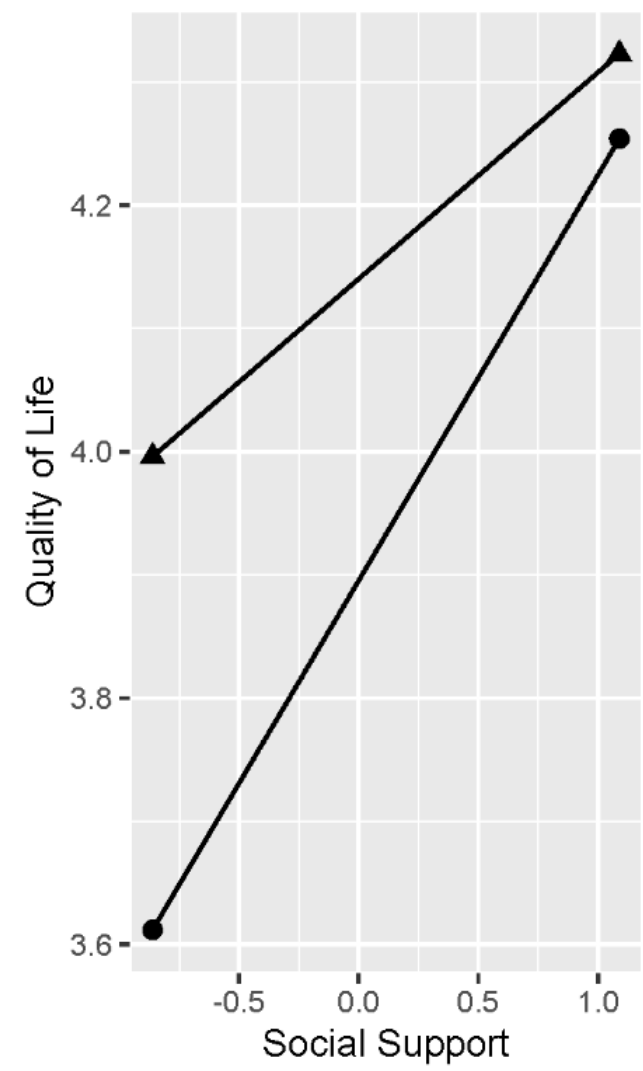

\section{Moderator}

- Low HealthLiteracy (-1 SD)

A High HealthLiteracy (+1 SD)

\section{Discussion}

\section{Relationship Between Health Literacy and Social Support and the Quality of Life in Patients With Cancer}

We identified significant effects of health literacy, social support, age, interaction of health literacy and social support, and interaction of social support and age on QOL for the patients with lung, stomach, or colon cancer. We also found that the effect of social support and age is stronger than that of health literacy when controlling for the effects of other independent variables. In addition, health literacy, social support, and their interaction were found to have a significant effect on QOL. Moreover, the effect of social support is stronger for low health literacy than for high health literacy in those 50 years or older, while there is no effect on the QOL in those younger than 50 years.

Studies involving patients with cancer have indicated that health literacy with respect to treatment is important for understanding a disease [14-16], and that health literacy is positively associated with QOL [23]. Previous results on social support have indicated that among older patients with cancer undergoing chemotherapy, QOL was higher for those with strong social support [37]. In this study, the levels of health literacy and social support were related to QOL. Moreover, the association was stronger for social support than for health literacy. These findings suggest that both health literacy and social support are important considerations for the QOL in patients with cancer.
Health literacy can be considered a patient resource [49]. Although efforts have been undertaken to increase health literacy, this is not easily accomplished [24-26]. Social support, on the other hand, is a resource provided by the people with whom the patient associates. Support from family members, friends, and acquaintances is what the patient is most familiar with, and thus, it is important to continue to strengthen such support. However, this support varies depending on the individual, and those providing support may have their own physical, emotional, social, or financial problems [50]. Consequently, a need for consulting services that specialize in social support has been suggested [51].

Efforts to provide a system of social support not dependent on individual circumstances have been implemented. Maggie's [52] centers were first established in Edinburgh in 1996. These centers provide free practical, emotional, and social support to patients with cancer and their friends and family members. There are currently 20 such centers in the United Kingdom (mainly in National Health Service cancer hospitals) and other countries, and an online center has been established. Because the centers are places that anyone can casually visit at any time, it is difficult to maintain records for each individual and measure the effectiveness of the centers. However, the results of this study indicate that although it is difficult to increase health literacy, an individual resource, improving social support may lead to increased QOL in patients with cancer. This reinforces the importance of efforts to improve and facilitate social support. 


\section{Quality of Life, Health Literacy, and Social Support According to Age}

Studies in older individuals have shown that QOL increases with health literacy and social support. This study showed similar positive associations between QOL and health literacy and social support in patients with cancer 50 years or older. Moreover, the association was stronger for social support than for health literacy. A negative association was observed with the interaction of health literacy and social support, but the coefficient was much lower than for health literacy and social support. Patients high in health literacy collect information actively and independently and come to conclusions based on that information. The information and support provided by people around the patient may be at odds with those conclusions. In that case, the patient may become confused by the discrepancy and not amenable to social support. A simple slope analysis of the interaction between health literacy and social support showed social support to be significantly associated with QOL regardless of the level of health literacy. However, the coefficient for social support was larger when health literacy was low than when it was high. This result differs from the finding that, in older individuals, social support was more positively associated with health in those high in health literacy [40]. This may be related to the fact that the participants in this study were patients with cancer. The finding that social support was more positively associated with QOL in patients with cancer 50 years or older with low health literacy may be explained as follows: increasing the social support of patients with cancer that have low health literacy can mitigate the negative effect of low health literacy on QOL, as was indicated in the 2004 report by Lee [33].

The results for patients with cancer younger than 50 years differed from patients with cancer 50 years or older. Studies in young patients with cancer have included those of the adolescents and young adults (AYA) generation. The QOL in the AYA generation patients with cancer has been found to be low [53-57]. Moreover, the financial, mental health, and support group services available for the AYA generation patients are inadequate [58-60], as these patients desire information on side effects, alternative treatment options, pregnancy and childbirth options, and long-term care [59,61,62]. The AYA generation patients have also been shown to fear a continual fight against cancer and to experience negative emotions related to financial problems, death, body image, and perceived stigmas $[62,63]$. Furthermore, the types of treatment, lack of insurance, and withdrawing from school or a job after diagnosis have negative effects on occupational and educational outcomes [63,64].
Relationships with friends, family members, and other cancer survivors have been shown to lead to improved QOL in the AYA generation patients $[60,62]$. However, siblings of these patients have been reported to experience high levels of psychological distress [65], and problems such as persistent negative emotions related to the diagnosis and stigma associated with cancer have been reported for the parents and caregivers of such patients [66]. Thus, it may be difficult for patients with cancer to receive adequate support from family members, who are the patients' closest supporters.

Similar to the AYA generation, patients younger than 50 years are affected by cancer early and must therefore cope with the disease for a long time, making the mental burden greater than that of patients aged 50 years or older. Because there are generally few patients with cancer in the same age group, it will be important to examine further ways to strengthen the social support system based on their needs.

\section{Limitations}

This retrospective study was conducted using an online survey. Consequently, a limitation of the study was that it was based on patient perceptions. Further investigations that consider factors such as the type and stage of cancer and the time since diagnosis are needed for young patients. Accordingly, it will be important to examine how to strengthen the support systems available to patients with cancer by elucidating their needs based on their current status.

\section{Conclusions}

The results of this study showed that the QOL in patients with cancer increased with health literacy, social support, and age. Moreover, the relationship with QOL was stronger for social support than for health literacy; similar results were obtained for patients with cancer 50 years or older. These findings suggest the importance of health literacy and social support, which has been noted previously, and indicate that the support of those around the patient has a greater effect on QOL than health literacy.

Different results were obtained for patients with cancer younger than 50 years. QOL in this group was lower than that in those 50 years or older. In view of the problems faced by younger patients with cancer, which have been identified in previous studies, elucidating the needs of these patients and further strengthening social support based on those needs may lead to improvements in QOL.

\section{Acknowledgments}

This work was supported by the Japan Society for the Promotion of Science through a Grant-in-Aid for Scientific Research (JP15H02752, JP18H03292). The funder had no role in the conduct of the study, writing of the manuscript, or decision to publish.

\section{Conflicts of Interest}

None declared.

\section{References}


1. Sørensen K, Van den Broucke S, Fullam J, Doyle G, Pelikan J, Slonska Z, (HLS-EU) Consortium Health Literacy Project European. Health literacy and public health: a systematic review and integration of definitions and models. BMC Public Health 2012 Jan 25;12:80 [FREE Full text] [doi: 10.1186/1471-2458-12-80] [Medline: 22276600]

2. Gazmararian JA, Baker DW, Williams MV, Parker RM, Scott TL, Green DC, et al. Health literacy among Medicare enrollees in a managed care organization. JAMA 1999 Feb 10;281(6):545-551. [doi: 10.1001/jama.281.6.545] [Medline: 10022111]

3. Baker DW, Parker RM, Williams MV, Clark WS, Nurss J. The relationship of patient reading ability to self-reported health and use of health services. Am J Public Health 1997 Jun;87(6):1027-1030. [doi: 10.2105/ajph.87.6.1027] [Medline: 9224190]

4. Sudore RL, Yaffe K, Satterfield S, Harris TB, Mehta KM, Simonsick EM, et al. Limited literacy and mortality in the elderly: the health, aging, and body composition study. J Gen Intern Med 2006 Aug;21(8):806-812 [FREE Full text] [doi: 10.1111/j.1525-1497.2006.00539.x] [Medline: 16881938]

5. O'Conor R, Wolf MS, Smith SG, Martynenko M, Vicencio DP, Sano M, et al. Health literacy, cognitive function, proper use, and adherence to inhaled asthma controller medications among older adults with asthma. Chest 2015 May;147(5):1307-1315 [FREE Full text] [doi: 10.1378/chest.14-0914] [Medline: 25275432]

6. Zhang NJ, Terry A, McHorney CA. Impact of health literacy on medication adherence: a systematic review and meta-analysis. Ann Pharmacother 2014 Jun;48(6):741-751. [doi: 10.1177/1060028014526562] [Medline: 24619949]

7. Fabbri M, Yost K, Finney Rutten LJ, Manemann SM, Boyd CM, Jensen D, et al. Health literacy and outcomes in patients with heart failure: a prospective community study. Mayo Clin Proc 2018 Jan;93(1):9-15 [FREE Full text] [doi: 10.1016/j.mayocp.2017.09.018] [Medline: 29217337]

8. Smith SG, O'Conor R, Curtis LM, Waite K, Deary IJ, Paasche-Orlow M, et al. Low health literacy predicts decline in physical function among older adults: findings from the LitCog cohort study. J Epidemiol Community Health 2015 May;69(5):474-480 [FREE Full text] [doi: 10.1136/jech-2014-204915] [Medline: 25573701]

9. Kobayashi LC, Wardle J, von Wagner C. Limited health literacy is a barrier to colorectal cancer screening in England: evidence from the English Longitudinal Study of Ageing. Prev Med 2014 Apr;61:100-105 [FREE Full text] [doi: 10.1016/j.ypmed.2013.11.012] [Medline: 24287122]

10. Parkin DM, Bray F, Ferlay J, Pisani P. Global cancer statistics, 2002. CA Cancer J Clin 2005;55(2):74-108 [FREE Full text] [doi: $10.3322 /$ canjclin.55.2.74] [Medline: 15761078$]$

11. Jemal A, Bray F, Center MM, Ferlay J, Ward E, Forman D. Global cancer statistics. CA Cancer J Clin 2011;61(2):69-90 [FREE Full text] [doi: 10.3322/caac.20107] [Medline: 21296855]

12. Torre LA, Bray F, Siegel RL, Ferlay J, Lortet-Tieulent J, Jemal A. Global cancer statistics, 2012. CA Cancer J Clin 2015 Mar;65(2):87-108 [FREE Full text] [doi: 10.3322/caac.21262] [Medline: 25651787]

13. Bray F, Ferlay J, Soerjomataram I, Siegel RL, Torre LA, Jemal A. Global cancer statistics 2018: GLOBOCAN estimates of incidence and mortality worldwide for 36 cancers in 185 countries. CA Cancer J Clin 2018 Sep 12;68(6):394-424 [FREE Full text] [doi: $10.3322 /$ caac. 21492] [Medline: $\underline{30207593}$ ]

14. Koay K, Schofield P, Jefford M. Importance of health literacy in oncology. Asia Pac J Clin Oncol 2012 Mar;8(1):14-23. [doi: 10.1111/j.1743-7563.2012.01522.x] [Medline: 22369440]

15. Amalraj S, Starkweather C, Nguyen C, Naeim A. Health literacy, communication, and treatment decision-making in older cancer patients. Oncology (Williston Park) 2009 Apr 15;23(4):369-375 [FREE Full text] [Medline: 19476267]

16. McCarthy DM, Waite KR, Curtis LM, Engel KG, Baker DW, Wolf MS. What did the doctor say? Health literacy and recall of medical instructions. Med Care 2012 Apr;50(4):277-282 [FREE Full text] [doi: 10.1097/MLR.0b013e318241e8e1] [Medline: 22411440]

17. Ngoh LN. Health literacy: a barrier to pharmacist-patient communication and medication adherence. J Am Pharm Assoc 2009;49(5):e132-e146. [doi: 10.1331/JAPhA.2009.07075] [Medline: 19748861]

18. World Health Organization. WHOQOL: measuring quality of life URL: https://www.who.int/healthinfo/survey/ whoqol-qualityoflife/en/ [accessed 2019-11-07]

19. Aziz NM, Miller JL, Curtis JR. Palliative and end-of-life care research: embracing new opportunities. Nurs Outlook 2012;60(6):384-390 [FREE Full text] [doi: 10.1016/j.outlook.2012.08.006] [Medline: 23141198]

20. Berkman ND, Sheridan SL, Donahue KE, Halpern DJ, Crotty K. Low health literacy and health outcomes: an updated systematic review. Ann Intern Med 2011 Jul 19;155(2):97-107. [doi: 10.7326/0003-4819-155-2-201107190-00005] [Medline: 21768583]

21. Davis TC, Williams MV, Marin E, Parker RM, Glass J. Health literacy and cancer communication. CA Cancer J Clin 2002;52(3):134-149 [FREE Full text] [doi: 10.3322/canjclin.52.3.134] [Medline: 12018928]

22. Song L, Mishel M, Bensen JT, Chen RC, Knafl GJ, Blackard B, et al. How does health literacy affect quality of life among men with newly diagnosed clinically localized prostate cancer? Findings from the North Carolina-Louisiana Prostate Cancer Project (PCaP). Cancer 2012 Aug 01;118(15):3842-3851 [FREE Full text] [doi: 10.1002/cncr.26713] [Medline: 22180041]

23. Halverson JL, Martinez-Donate AP, Palta M, Leal T, Lubner S, Walsh MC, et al. Health literacy and health-related quality of life among a population-based sample of cancer patients. J Health Commun 2015;20(11):1320-1329 [FRE Full text] [doi: 10.1080/10810730.2015.1018638] [Medline: 26161549] 
24. US Department of Health and Human Services, Office of Disease Prevention and Health Promotion. National Action Plan to Improve Health Literacy. URL: https://health.gov/sites/default/files/2019-09/Health Literacy Action Plan.pdf [accessed 2019-11-07]

25. Health Care 2035 Advisory Panel. The Japan Vision: Health Care 2035 Final Report.: Ministry of Health, Labour and Welfare, Japan; 2015 Jun. URL: https://www.y-shiozaki.or.jp/contribution/pdf/20151221132002 77dW.pdf [accessed 2019-11-07]

26. Nutbeam D, McGill B, Premkumar P. Improving health literacy in community populations: a review of progress. Health Promot Int 2018 Oct 01;33(5):901-911. [doi: 10.1093/heapro/dax015] [Medline: 28369557]

27. Jessup RL, Osborne RH, Beauchamp A, Bourne A, Buchbinder R. Health literacy of recently hospitalised patients: a cross-sectional survey using the Health Literacy Questionnaire (HLQ). BMC Health Serv Res 2017 Jan 19;17(1):52 [FREE Full text] [doi: 10.1186/s12913-016-1973-6] [Medline: 28103914]

28. Jansen L, Koch L, Brenner H, Arndt V. Quality of life among long-term ( $\geq 5$ years) colorectal cancer survivors--systematic review. Eur J Cancer 2010 Nov;46(16):2879-2888. [doi: 10.1016/j.ejca.2010.06.010] [Medline: 20605090]

29. Sun V, Borneman T, Koczywas M, Cristea M, Piper BF, Uman G, et al. Quality of life and barriers to symptom management in colon cancer. Eur J Oncol Nurs 2012 Jul;16(3):276-280 [FREE Full text] [doi: 10.1016/j.ejon.2011.06.011] [Medline: 21783415]

30. Gupta D, Lis CG, Granick J, Grutsch JF, Vashi PG, Lammersfeld CA. Malnutrition was associated with poor quality of life in colorectal cancer: a retrospective analysis. J Clin Epidemiol 2006 Jul;59(7):704-709. [doi: 10.1016/j.jclinepi.2005.08.020] [Medline: 16765273]

31. Gogou P, Tsilika E, Parpa E, Kouvaris I, Damigos D, Balafouta M, et al. The impact of radiotherapy on symptoms, anxiety and QoL in patients with cancer. Anticancer Res 2015 Mar;35(3):1771-1775. [Medline: 25750341]

32. de la Torre-Luque A, Gambara H, López E, Cruzado JA. Psychological treatments to improve quality of life in cancer contexts: a meta-analysis. Int J Clin Health Psychol 2016;16(2):211-219 [FREE Full text] [doi: 10.1016/j.ijchp.2015.07.005] [Medline: 30487864]

33. Lee SY, Arozullah AM, Cho YI. Health literacy, social support, and health: a research agenda. Soc Sci Med 2004 Apr;58(7):1309-1321. [doi: 10.1016/S0277-9536(03)00329-0] [Medline: 14759678]

34. Polanski J, Jankowska-Polanska B, Rosinczuk J, Chabowski M, Szymanska-Chabowska A. Quality of life of patients with lung cancer. Onco Targets Ther 2016;9:1023-1028 [FREE Full text] [doi: 10.2147/OTT.S100685] [Medline: 27013895]

35. Pinquart M, Duberstein PR. Associations of social networks with cancer mortality: a meta-analysis. Crit Rev Oncol Hematol 2010 Aug;75(2):122-137 [FREE Full text] [doi: 10.1016/j.critrevonc.2009.06.003] [Medline: 19604706 ]

36. Doran P, Burden S, Shryane N. Older people living well beyond cancer: the relationship between emotional support and quality of life. J Aging Health 2019 Dec;31(10):1850-1871. [doi: 10.1177/0898264318799252] [Medline: 30198352]

37. Robb C, Lee A, Jacobsen P, Dobbin KK, Extermann M. Health and personal resources in older patients with cancer undergoing chemotherapy. J Geriatr Oncol 2013 Apr;4(2):166-173 [FREE Full text] [doi: 10.1016/j.jgo.2012.12.002] [Medline: 24071541]

38. Gonzalez-Saenz de Tejada M, Bilbao A, Baré M, Briones E, Sarasqueta C, Quintana JM, et al. Association of social support, functional status, and psychological variables with changes in health-related quality of life outcomes in patients with colorectal cancer. Psychooncology 2016 Aug;25(8):891-897. [doi: 10.1002/pon.4022] [Medline: 26582649]

39. Smith SG, Jackson SE, Kobayashi LC, Steptoe A. Social isolation, health literacy, and mortality risk: Findings from the English Longitudinal Study of Ageing. Health Psychol 2018 Feb;37(2):160-169 [FREE Full text] [doi: 10.1037/hea0000541] [Medline: 29172607]

40. Lee SD, Arozullah AM, Cho YI, Crittenden K, Vicencio D. Health literacy, social support, and health status among older adults. Educational Gerontology 2009 Feb 04;35(3):191-201. [doi: 10.1080/03601270802466629]

41. American Cancer Society. Cancer Facts \& Figures 2019. Atlanta: American Cancer Society; 2019. URL: http://www. cancer.org/content/dam/cancer-org/research/cancer-facts-and-statistics/annual-cancer-facts-and-figures/2019/ cancer-facts-and-figures-2019.pdf [accessed 2019-11-07]

42. Cancer Research UK. Cancer incidence by age URL: https://www.cancerresearchuk.org/health-professional/cancer-statistics/ incidence/age [accessed 2019-11-07]

43. The Editorial Board of the Cancer Statistics in Japan. Cancer Statistics in Japan 2015. Tokyo: Foundation for Promotion of Cancer Research; 2015. URL: https://ganjoho.jp/data/reg stat/statistics/brochure/2015/cancer statistics 2015.pdf [accessed 2019-11-07]

44. Nakayama K, Osaka W, Togari T, Ishikawa H, Yonekura Y, Sekido A, et al. Comprehensive health literacy in Japan is lower than in Europe: a validated Japanese-language assessment of health literacy. BMC Public Health 2015 May 23;15:505 [FREE Full text] [doi: 10.1186/s12889-015-1835-x] [Medline: 26001385]

45. Dahlem NW, Zimet GD, Walker RR. The multidimensional scale of perceived social support: a confirmation study. J Clin Psychol 1991 Nov;47(6):756-761. [doi: 10.1002/1097-4679(199111)47:6<756::aid-jclp2270470605>3.0.co;2-1] [Medline: $\underline{1757578]}$ 
46. Iwasa H, Gondo Y, Masui Y, Inagaki H, Kawai C, Otuka R, et al. Reliability and validity of a Japanese language version of the Multidimensional Scale of Perceived Social Support. J Health and Welfare Statistics (in Japanese) 2007 Jun;54(6):26-33 [FREE Full text]

47. FACIT.org. FACT-G7: Functional Assessment of Cancer Therapy - General - (7 item version; be used with patients of any tumor type) URL: https://www.facit.org/FACITOrg/Questionnaires [accessed 2019-11-07]

48. Yanez B, Pearman T, Lis CG, Beaumont JL, Cella D. The FACT-G7: a rapid version of the functional assessment of cancer therapy-general (FACT-G) for monitoring symptoms and concerns in oncology practice and research. Ann Oncol 2013 Apr;24(4):1073-1078 [FREE Full text] [doi: 10.1093/annonc/mds539] [Medline: 23136235]

49. Ishikawa H, Kiuchi T. Association of health literacy levels between family members. Front Public Health 2019;7:169 [FREE Full text] [doi: 10.3389/fpubh.2019.00169] [Medline: 31275918 ]

50. Kuscu MK, Dural U, Onen P, Yaşa Y, Yayla M, Basaran G, et al. The association between individual attachment patterns, the perceived social support, and the psychological well-being of Turkish informal caregivers. Psychooncology 2009 Sep;18(9):927-935. [doi: 10.1002/pon.1441] [Medline: 19140124]

51. Kahriman F, Zaybak A. Caregiver burden and perceived social support among caregivers of patients with cancer. Asian Pac J Cancer Prev 2015;16(8):3313-3317 [FREE Full text] [doi: 10.7314/apjcp.2015.16.8.3313] [Medline: 25921137]

52. Maggie's. Glasgow, UK: The Maggie Keswick Jencks Cancer Caring Centres Trust URL: https://www.maggiescentres.org/ [accessed 2019-11-07]

53. Kirchhoff AC, Spraker-Perlman HL, McFadden M, Warner EL, Oeffinger KC, Wright J, et al. Sociodemographic disparities in quality of life for survivors of adolescent and young adult cancers in the behavioral risk factor surveillance system. J Adolesc Young Adult Oncol 2014 Jun 01;3(2):66-74 [FREE Full text] [doi: 10.1089/jayao.2013.0035] [Medline: 24940530]

54. Geue K, Sender A, Schmidt R, Richter D, Hinz A, Schulte T, et al. Gender-specific quality of life after cancer in young adulthood: a comparison with the general population. Qual Life Res 2014 May;23(4):1377-1386. [doi:

10.1007/s11136-013-0559-6] [Medline: 24197479]

55. Smith AW, Bellizzi KM, Keegan THM, Zebrack B, Chen VW, Neale AV, et al. Health-related quality of life of adolescent and young adult patients with cancer in the United States: the Adolescent and Young Adult Health Outcomes and Patient Experience study. J Clin Oncol 2013 Jun 10;31(17):2136-2145 [FREE Full text] [doi: 10.1200/JCO.2012.47.3173] [Medline: 23650427]

56. Kazak AE, Derosa BW, Schwartz LA, Hobbie W, Carlson C, Ittenbach RF, et al. Psychological outcomes and health beliefs in adolescent and young adult survivors of childhood cancer and controls. J Clin Oncol 2010 Apr 20;28(12):2002-2007 [FREE Full text] [doi: 10.1200/JCO.2009.25.9564] [Medline: 20231679]

57. Quinn GP, Gonçalves V, Sehovic I, Bowman ML, Reed DR. Quality of life in adolescent and young adult cancer patients: a systematic review of the literature. Patient Relat Outcome Meas 2015;6:19-51 [FREE Full text] [doi: 10.2147/PROM.S51658] [Medline: 25733941]

58. Smith AW, Parsons HM, Kent EE, Bellizzi K, Zebrack BJ, Keel G, AYA HOPE Study Collaborative Group. Unmet support service needs and health-related quality of life among adolescents and young adults with cancer: the AYA HOPE study. Front Oncol 2013;3:75 [FREE Full text] [doi: 10.3389/fonc.2013.00075] [Medline: 23580328]

59. Keegan THM, Lichtensztajn DY, Kato I, Kent EE, Wu XC, West MM, AYA HOPE Study Collaborative Group. Unmet adolescent and young adult cancer survivors information and service needs: a population-based cancer registry study. $\mathrm{J}$ Cancer Surviv 2012 Sep;6(3):239-250 [FREE Full text] [doi: 10.1007/s11764-012-0219-9] [Medline: 22457219]

60. Kent EE, Smith AW, Keegan THM, Lynch CF, Wu XC, Hamilton AS, et al. Talking about cancer and meeting peer survivors: social information needs of adolescents and young adults diagnosed with cancer. J Adolesc Young Adult Oncol 2013 Jun;2(2):44-52 [FREE Full text] [doi: 10.1089/jayao.2012.0029] [Medline: 23781400]

61. Geue K, Richter D, Schmidt R, Sender A, Siedentopf F, Brähler E, et al. The desire for children and fertility issues among young German cancer survivors. J Adolesc Health 2014 May;54(5):527-535. [doi: 10.1016/j.jadohealth.2013.10.005] [Medline: 24315429]

62. Cooke L, Chung C, Grant M. Psychosocial care for adolescent and young adult hematopoietic cell transplant patients. J Psychosoc Oncol 2011;29(4):394-414 [FREE Full text] [Medline: 21966725]

63. Bellizzi KM, Smith A, Schmidt S, Keegan THM, Zebrack B, Lynch CF, Adolescent and Young Adult Health Outcomes and Patient Experience Study Collaborative Group. Positive and negative psychosocial impact of being diagnosed with cancer as an adolescent or young adult. Cancer 2012 Oct 15;118(20):5155-5162 [FREE Full text] [doi: 10.1002/cncr.27512] [Medline: 22415815]

64. Parsons HM, Harlan LC, Lynch CF, Hamilton AS, Wu XC, Kato I, et al. Impact of cancer on work and education among adolescent and young adult cancer survivors. J Clin Oncol 2012 Jul 01;30(19):2393-2400 [FREE Full text] [doi: 10.1200/JCO.2011.39.6333] [Medline: 22614977]

65. Santacroce SJ, Crandell JB. Feasibility and preliminary findings from a pilot study of allostatic load in adolescent-young adult childhood cancer survivors and their siblings. J Pediatr Oncol Nurs 2014;31(3):122-134. [doi:

10.1177/1043454213520190] [Medline: 24647010] 
66. Casillas J, Kahn KL, Doose M, Landier W, Bhatia S, Hernandez J, Padres Contra El Cáncer. Transitioning childhood cancer survivors to adult-centered healthcare: insights from parents, adolescent, and young adult survivors. Psychooncology 2010 Sep;19(9):982-990. [doi: 10.1002/pon.1650] [Medline: 20017115]
Abbreviations
AYA: adolescents and young adults
FACT-G: Functional Assessment of Cancer Therapy-General
FACT-G7: Functional Assessment of Cancer Therapy-General (7-item version)
HLS-EU-Q47: European Health Literacy Survey Questionnaire
QOL: quality of life

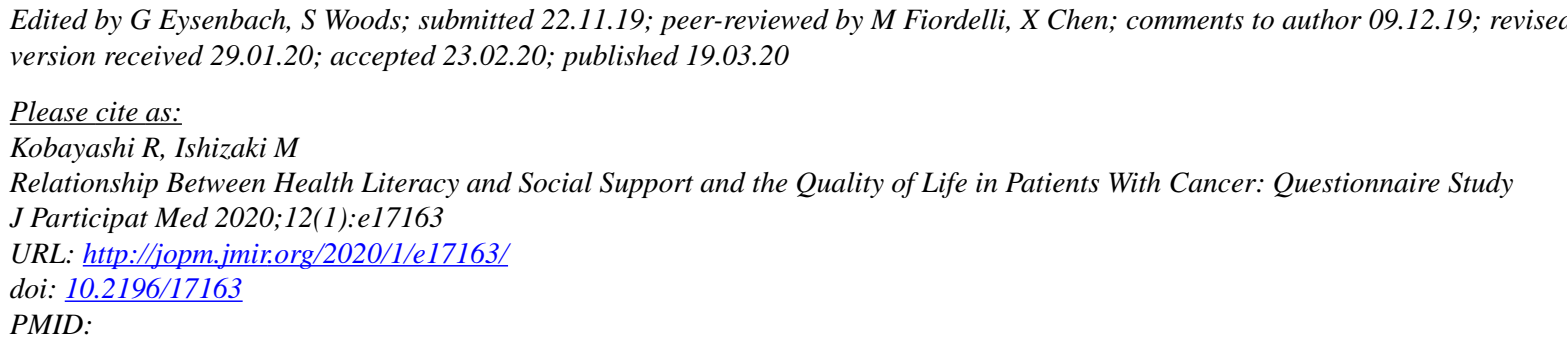

CRei Kobayashi, Masato Ishizaki. Originally published in Journal of Participatory Medicine (http://jopm.jmir.org), 19.03.2020. This is an open-access article distributed under the terms of the Creative Commons Attribution License (https://creativecommons.org/licenses/by/4.0/), which permits unrestricted use, distribution, and reproduction in any medium, provided the original work, first published in Journal of Participatory Medicine, is properly cited. The complete bibliographic information, a link to the original publication on http://jopm.jmir.org, as well as this copyright and license information must be included. 